\title{
Limited Reverse Evidentiary System in the Basic Perspective of Presumption of Innocence
}

\author{
Sugeng Riyadi ${ }^{1}$, Zudan Arief Fakrulloh ${ }^{2}$ \\ Borobudur University, Indonesia ${ }^{1,2}$ \\ \{sugengunboro@gmail.com ${ }^{1}$, cclsis@yahoo.com ${ }^{2}$ \}
}

\begin{abstract}
The Reverse Proof System is Limited and Balanced based on Article 77 of Law No. 8 of 2010 and the provisions of kuhap. The evidence of the reverse is limited and balanced", that the defendant has the right to prove that he did not commit the crimes alleged against him and the public prosecutor is still obliged to prove his indictment. The arrangement creates concerns for perpetrators of money laundering crimes, because the reverse evidentiary system can not necessarily be implemented optimally, given that there are some juridical problems that are likely to occur, namely contrary to the Basic Principles of Criminal Law, namely the principle of presumption of innocence. On the other hand, the system adopted is also contrary to Law No. 48 of 2009, that which can bring out the wrong verdict or not a person is a judge. This research method uses normative juridical research. The result of this research is that the provisions of Article 77 of Law No. 8 of 2010 need to be changed so as to provide legal certainty for the accused and not contrary to the principle of presumption of innocence and the system adopted in Law No. 48 of 2009.
\end{abstract}

Keywords: Money Laundring; Limited Reverse Proof System; Principle of Presumption of Innocence

\section{Introduction}

Money laundering as an internationally charged crime is not new in many countries including Indonesia. Such crimes certainly have a tremendous negative impact on a country's economy, so that countries in the world and international organizations feel encouraged and motivated to pay more serious attention to the prevention and eradication of money-laundering crimes. Influence bad that it causes greatly against the pencucian of money, such as the instability of the financial system, and the instability of the economic system of the State and even the world as awhole, because of money laundering activities as a transnational crime (transnational crime) that mode many cross borders .

The development of technology isadvancingrapidly, bringing aspirit to the development in various sectors, both in the political, economic, socio-cultural, one of the growing problem is criminality, but the legal tools to prevent and eradicate criminality itself is not adequate and still far away, so that various types of crimes either committed by individuals, groups or corporations easily occur, and produce a large amount of wealth, these crimes are not only committed within the boundaries of a country,but extend across the borders of other countries 
so often referred to as transnational crime, in transnational crimes the proceeds of crime are usually committed by perpetrators hidden, then expelled again as if from legalresults.

Money laundering (TPPU) is a transnational organized crime, in its eradication is often related to the jurisdiction of other countries so that it requires international cooperation. Indonesia and a number of other countries deemed less cooperative are included in the Non Cooperative Countries and Territories list for the eradication of money laundering since June 2001 by the Financial Action Task Force on Money Laundering (FATF) a task force of 31 countries and 2 regional organizations. Regulated policies are in the areas of regulation, finance and law enforcement and are set forth in $40+9$ FATF recommendations. Fatf institutions then demanded that countries be able to join in the figures eradicating money laundering crimes. In the lawsuit mentioned Indonesia until 2001 has not met these demands, therefore Indonesia is blacklisted non cooperative countries and territories (NCCTs List) issued by fatf because it is considered as a country prone to money laundering. Although Indonesia has never been a member of the FATF, Indonesia is still judged by the FATF.[1]

Indonesia is one of the countries that is quite open to be the target of money bleaching, because in Indonesia there are potential factors as an attraction for money laundering actors, a combination of social system weaknesses and the rule of law in the financial system, among others, a free foreign exchange system, not followed by the origin of investment and development of capital markets, foreign exchange traders and banking networks that have expanded abroad. With the magnitude of the impact on the stability of the country's economy, a number of countries have set strict enough rules to disclose money laundering.[2]

Indonesia has prohibited "money laundering" through Law No. 15 of 2002 on Money Laundering Crimes as amended into LawNo. 25 of 2003 on Money Laundering Crimes, and was last amended again by Law No. 8 of 2010 on prevention and eradication of money laundering crimes. The definition of money laundring that in Article 1 number 1 as follows: "Money laundering is the act of placing, transferring, paying, spending, giving, donating, depositing, bringing abroad, exchanging, or other acts of property that he knows or should be suspected of being the result of a criminal act with the intention to hide, or disguise the origin of the property so that it appears to be a legitimate property."

Various efforts and efforts of the Indonesian government, one of which is to suppress the rise of criminal acts of money laundering or money laundring is to pay special attention in the aspect of proof. The evidence referred to on the side is related to whether or not the accused committed the alleged act, being the most important part that must be considered in the criminal procedural law as well as on human rights.

The application in the provisions of Article 77 of Law No. 8 of 2010 applies or adheres to two evidentiary systems, namely "a limited and balanced reverse evidentiary system" and a "negative system" as stipulated in kuhap. Because the reverse proof system embraced by the TPPU Law can not necessarily be implemented optimally, considering there are some juridical problems that may occur, such as the contradictionof this reverse proof system with the Basic Law principle of Criminal Law that is the principleof presumption of innocence (presumption of innocence). Looking at the description above, then in this paper the author wants to examine "Limited Reverse Evidentiary System In The Perspective of the Principle of Presumption of Innocence"

\section{Research Methods}


The method used in the form of normative juridical research using the statute approach is used in researching, reviewing, studying, understanding the laws and regulations governing the Limited Reverse Proof System in the Perspective of the Principle of Presumption of Innocence.

\section{Results and Discussions}

3.1 Understanding Money Laundring, Actors Money Laundring and Understanding the System of Reverse Proof is Limited

\subsubsection{Understanding and History of Money Laundering}

The term, "money laundering" is a translation of "money launderin," which as the actual term has not been used for a long time. The term money laundering has been known since 1930 in the United States. At that time this crime was carried out by the criminal organization "mafia" through the purchase of laundry companies which were then used by the organization as a place of money laundering resulting from illegal businesses such as gambling, prostitution, and liquor trafficking. However, simply money laundering can be interpreted as a process that is done to change the money from the proceeds of crime, so that the money from the crime becomes visible as the result of legitimate activities because its origin has been disguised or hidden. [3]

\subsubsection{Perpetrators Money Laundring}

In the science of criminal law, outward deeds are known as actus reus, while the mental condition or heart attitude of the perpetrator of the act is called mens rea. Thus, actus reus is an external element, while mens rea is a fault element or mental element. It means that actus reus concerns unlawful acts (unlawful act) while mens rea includes elements of the maker of criminal acts that are mental attitudes called subjective elements of a criminal act or psychic state of the maker.

As mentioned above the error itself in the criminal law is divided into two, namely intentionality (dolus) and error (culpa). Most crimes have an element of intentionality not a culpa element. This is feasible because usually the person who deserves a criminal penalty is the one who does something intentionally. Intentionality according to the memory of the explanation means that a person who performs an act intentionally, must desire and instigate the action and/or its consequences. When discussing 'intentionality' it should be about three elements of the criminal act that is prohibited, the consequences of which are the main reasons for the prohibition and that the act is unlawful. [4]

In general, people who commit crimes by accident involving profits in the form of large amounts of money will try in various ways to hide or disguise the origin of his wealth which is the result of a criminal act so that it is difficult to be traced by law enforcement. If the perpetrator of the crime can hide or dispense the wealth resulting from his crime then he can then use his wealth, either to be enjoyed or used in other activities, both legitimate activities and unauthorized activities.

The crimes contained in the events previously stated include two kinds of crimes, namely, the first criminal act in the form of a criminal act that generates wealth for the perpetrator of a crime, such as corruption or narcotics / psychotropic crimes, while the second criminal act, in 
the form of hiding or disguising property obtained from the first crime. This second crime is known as money laundering.

Perpetrators who commit money laundering crimes are regulated in the provisions of Article 3 to Article 6 Laws No. 8 of 2010 concerning the prevention and eradication of money laundering crimes are:

1. Any Person who places, transfers, transfers, spends, pays, gives, entrusts, carries abroad, changes the form, exchanges for currency or securities or other acts of Wealth that he knows or should be suspected to be the result of a criminal act.

2. Any Person who conceals or disguises the origin, source, location, designation, transfer of rights, or actual ownership of Assets known or supposed to be the result of a criminal act.

3. Any Person who receives or controls the placement, transfer, payment, grant, donation, custody, exchange, or use of Assets that he or she knows or should suspect is the result of a criminal offence.

4. In the event that the money laundering crime as referred to in numbers 1 to number 3 is committed by the Corporation, the criminal is imposed against the Corporation and/or the Corporate Controlling Personnel.

\subsubsection{Limited Definition of Reverse Proof System}

Initially the limited reverse evidentiary system originated from a country that adhered to Anglo Saxon law and its application was limited in certain cases, such as corruption, gratification, bribery, and money laundering cases. The definition of "limited reverse proof system" is contained in the provisions of Article 77 of Law No. 8 of 2010, which adheres to two evidentiary systems, namely "a limited and balanced reverse evidentiary system" and a "negative system"as stipulated in kuhap. In the explanation of Law No. 8 of 2010, the definition of "limited and balanced reverse proof", i.e. the defendant has the right to prove that he did not commit the crimes alleged against him and the public prosecutor is still obliged to prove his indictment. The words "limited" are intended that if the accused can confidently prove that the allegations directed against him are not proven or untrue, this does not mean that the defendant did not commit a criminal offence in accordance with what was alleged by the JPU. Because JPU, still obliged to prove the indictment.

\subsection{Limited Reverse Evidentiary System and the Principle of Presumption of Innocence}

\subsubsection{Limited Reverse Proofing System}

It is necessary to first discuss related to various types related to Proof. In perpektif knowledge of Criminal Law known there are 3 (three) theories about the burden of proof are as follows:

\section{a) Burden of Proof on the Public Prosecutor}

The public prosecutor does not exercise the right to deny the rightsgranted by u-law to the accused, but does not mean that the public prosecutor does not have the right to judge from the point of view of the public prosecutor in his requisitor. The logical consequence of this evidentiary burden theory, that the Public Prosecutor must prepare evidence and evidence accurately, because otherwise it will be difficult to convince the judge about the defendant's 
guilt. The logical consequences of the burden of proof are on the Public Prosecutor this correlates the principle of presumption of innocence and actualization of the principle of not blaming oneself.

This theory of evidentiary burden is known in Indonesia that the provisions of Article 66 kuhap expressly state that, "suspects or defendants are not burdened with evidentiary obligations". Such evidentiary loads can be categorized as "ordinary" or "conventional" evidentiary loads.

\section{b) Burden of Proof on the Accused}

The defendant actively stated that he was not a criminal. Therefore, the defendant is in front of a court hearing that will prepare all the burdens of proof and if it can not prove, the defendant is found guilty of a criminal offence.

\section{c) Balanced Evidentiary Load}

Concreteization of this principle both the Public Prosecutor and the accused and / or his Legal Counsel prove each other before the trial. The theory of reversal of the burden of proof is "limited and balanced" in the sense that the accused and the Claimant prove each other's guilt or innocence. When viewed intensely, in detail and detail, in the provisions of Article 77 of Law No. 8 of 2010 apply or adhere to two evidentiary systems, namely "a limited and balanced reverse evidentiary system" and a "negative system" as stipulated in kuhap.

Explanation of Law No. 8 of 2010, the definition of "limited and balanced reverse proof", i.e. the defendant has the right to prove that he did not commit the crimes charged against him and the public prosecutor remains obliged to prove his indictment. The words "limited" are intended that if the accused can confidently prove that the allegations directed against him are not proven or untrue, this does not mean that the defendant did not commit a criminal offence in accordance with what was alleged by the JPU. Because JPU, still obliged to prove the indictment.

In a narrow sense, the evidentiary system refers to the provisions on standards in terms of proving something in casu the defendant's guilt in committing the alleged crime, as in the negative system according to the limited law (negatief wettelijk) as stipulated in Article 183 kuhap. The standard for stating whether or not a defendant's guilt is proven is first, must exist or be based on at least two valid pieces of evidence; secondly, from the two pieces of evidence the judge obtained a conviction for a criminal offence and the defendant was guilty of doing so. While the evidentiary loading system refers to which party is burdened with the obligation to prove and what should be proven, also about the standard gauge to determine provenaction.

Based on the understanding of the evidentiary system and the evidentiary loading system above, the specificity in the criminal procedure of money laundering refers more to the burden of proof system. Basically the evidentiary system is the same as applying Article 183 kuhap, especially for judges in assessing evidence tools. The standard that must be followed to state the provenness of the accused to commit the alleged crime remains bound by the provisions of Article 183 kuhap. This is a basic provision or legal basis for proof of criminal events that is not easily preserved by the law of proof of special criminal events, so it is different from what is often heard that the evidentiary system in money laundering crimes has adhered to the actual reverse system that is meant to be an inverted evidentiary loading system.

Although the application of the reverse evidentiary system is contrary to the principle of presumption of innocence stipulated in kuhap, but in this case applies the principle of lex 
specialis derogat lex generalis, in addition to the application of reverse proof is one of the ways that can be taken to eradicate money laundering crimes in Indonesia. The application of reverse proof against money laundering crimes is on the one hand detrimental to the accused, because his rights are less protected, but on the other hand this will bring greater benefits to many people, because it can reduce money laundering crimes that have harmed thestate.

Related to this serious crime, action or quick steps have been taken by the government by inviting Law No. 15 of 2002 which was refined into Law No. 25 of 2003 which has now been amended into Law No. 8 of 2010 on the Prevention and Eradication of Money Laundering Crimes. The product ofMoney Laundering law, is a form of commitment, understanding and political will of the Indonesian state to combat the problem of money laundering. This concept is a revolutionary policy outlined in this regulation is the use of the burden of proof upside down (Omkering van het Bewijslat).

Give the defendant the right to explain and help facilitate the proceedings of the indictment that has previously been traced by the Public Prosecutor. It is based on Article 78 of Law Nomor 8 Year 2010 paragraph (1) states that, in the examination at the court session as referred to in Article 77, the judge ordered the defendant to prove the property related to the case is not derived or related to the criminal act as referred to in Article2 paragraph (1). Then in paragraph (2) states "the accused proves the property related to the case does not originate or related to the criminal act as referred to in Article 2 paragraph (1) by submitting sufficient evidence.

\subsubsection{The Principle of Presumption of Innocence in the Reverse Evidentiary System}

The Basic Concept of Presumption of Innocence inIndonesia. That the principle of presumption of innocence is basically a manifestation of the function of criminal justice (modern) that is deliberately used as a principle in carrying out acts of violent takeover or retaliation of an institution appointed by the state. As such, all infringement of rights committed by a person must be resolved in accordance with applicable legal procedures

In Indonesia, the BasicLawof 1945 does not explicitly apply in one particular Article on the principle of presumption of guilt. This principle can be found in the implementation legislation, namely in Law No.14 of 1970 as amended by Law No. 35 of 1999 which was replaced by Law No. 4 of 2004 on The Power of Justice and replaced again with Law No. 48 of 2009 on Judicial Power. Law No. 39 of 1999 on Human Rights, Law No. 8 of 1981 on Criminal Procedural Law and Chapter III of the Decree of the Minister of Justice of the Republic of Indonesia Number M.01PW.07.03 Thun 1982 concerning Guidelines for the Implementation of the Criminal Procedure Law.

In addition to the Criminal Code and The Basic Law1945 in Law No. 48 of 2009 on the Power of Justice expressly stated in Article 8 Paragraph (1) which states that, "Every person who is suspected, arrested, detained, prosecuted, and /or confronted before the Court, must be considered innocent before the court's decision, which states his guilt that obtains a permanent legal force." Meanwhile, in Law No.8 of 1981, the principle of presumption of innocence is not expressly stated in any of the articles, but it is implied in the section considering the number 3 and in the General Explanation number 3 letter c.

When looking back at the explanation above how important it is to pay attention to the proper functioning of the Principle of Legality in the System of proof is limited according to Law Nomor 8 year 2010 because based onthe analysis of the author, it is considered to be potentially stab human rights because it is contrary to the principle of presumption of innocence (presumption of innocence), because if seen from the sound of Article 77 "The 
defendant has the right to prove that he did not commit the crime charged against him and the public prosecutor remains obliged to prove his indictment". Whereas when referring to the principle of legality it is said that a person can not be found guilty before there is a court ruling that inkhract van bewist gedaan, meaning the defendant plays an active role in the evidence. In addition to the system embraced by Law No. 8 of 2010 on the reverse evidentiary system, not only kuhap but also contrary to Law No. 48 of 2009 concerning Ehakiman K, that which can issue a wrongful verdict or not a person is a judge.

\section{Conclusions and Suggestions}

\subsection{Conclusion}

That in the explanation of Law No. 8 of 2010, Concerning Money Laundering Crimes, that the System of "inverse proof of a limited and balanced" nature, namely the defendant has the right to prove that he did not commit the crimes alleged against him and the public prosecutor remains obliged to prove his indictment. It is meant by a "limited nature" that if the accused can confidently prove that the allegations directed against him are not proven or untrue, this does not mean that the defendant did not commit a criminal offence in accordance with what was alleged by the JPU. Because JPU, still obliged to prove the indictment.

\subsection{Advice}

Based on the results of the author's analysis that it is important to pay attention to the proper functioning of the Principle of Legality in the application of the system "Limited Reverse Proof" in Law Nomor 8 year 2010, because based onthe analysis of the author, it is considered that it can potentially puncture human rights because it is contrary to the principle of presumption of innocence (presumption of innocence), because when viewed from the sound ofArticle 77 "The defendant has the right to prove that he did not commit the crime charged against him and the public prosecutor remains obliged to prove his indictment". Whereas when referring to the principle of legality is said that a person can not be found guilty before there is a court ruling that inkhract van bewist gedaan, meaning thedefendant plays an active role against the bullyn.

\section{References}

[1] R. Saputra, "Kewenangan Penuntutan Komisi Pemberantasan Korupsi (Kpk) Pada Kasus Tindak Pidana Pencucian Uang,” J. Huk. Respublica, vol. 16, no. 1, pp. 103 119, 2018, doi: 10.31849/respublica.v16i1.1429.

[2] A. Ayumiati, "Tindak Pidana Pencucian Uang (Money Laundering) Dan Strategi Pemberantasan," LEGITIMASI J. Huk. Pidana dan Polit. Huk., vol. 1, no. 2, pp. 19992003, 2017, doi: 10.22373/legitimasi.v1i2.1428.

[3] E. Waluyo, "Upaya Memerangi Tindakan Pencucian Uang (Money Laundring) Di Indonesia," J. Din. Huk., vol. 9, no. 3, pp. 237-246, 2009, doi: 10.20884/1.jdh.2009.9.3.235.

[4] S. M. Lestari, "Pertanggungjawaban Pidana Pasal 5 Undang-Undang Nomor 8 Tahun 2010 Tentang Pencegahan Dan Pemberantasan Tindak Pidana Pencucian Uang 
Ditinjau," Badamai Law J., vol. 2, no. 1, p. 95, 2017, doi: 10.32801/damai.v2i1.3389.

[5] E. R. Barus, T. K. D. A, and A. Arif, "Jurnal Mercatoria," J. Mercat., vol. 1, no. 1, pp. 79-98, 2017, [Online].

Available: http://ojs.uma.ac.id/index.php/mercatoria/article/view/731/643.

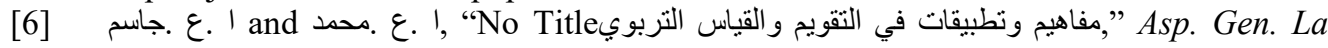
Planif. Tribut. En Venez., vol. 2009, no. 75, pp. 31-47, 2009. 